\title{
Media for the Enumeration and Isolation of Heterotrophic Salt-Marsh Bacteria
}

\author{
BY T. R. G. GRAY* \\ Department of Botany, University of Nottingham
}

(Received 12 November 1962)

SUMMARY

An investigation was made into the relative merits of several media for counting salt-marsh bacteria. Although extracts of salt-marsh mud were superior to extracts of meadow soil, a nitrogenous medium, i.e. ZoBell's sea-water agar no. 2216, was apparently the least selective. For the saltmarsh muds studied, media with a salinity about the same as sea water gave the highest counts of bacteria, particularly for samples from the salicornietum. A possible correlation between this and the origin of the mud is discussed.

\section{INTRODUCTION}

Early studies of soil bacteria showed that media containing meat extract or other rich nitrogenous nutrients (e.g. sodium albuminate) were very selective for certain groups of soil bacteria. Indeed the work of Waksman (1922), Smith \& Worden (1925), Lochhead \& Chase (1943) and others led to the general use of soil-extract media for the isolation and enumeration of soil bacteria, and to the view that these were the least selective media available. Media used to isolate marine bacteria have usually been based on rich nitrogenous substances also, although fish extract was sometimes substituted for meat extract (Fischer, 1894). During recent years such media have been simplified and ZoBell (1941) proposed the use of a sea-water agar containing only $0.5 \%$ peptone and $0.01 \%$ ferric phosphate. Subsequently this medium was used widely, for example by Wood (1953) in Australia, Velankar (1955) in India, and Hudleston (1955) in Wales. Modifications of this medium have also been suggested (Oppenheimer \& ZoBell, 1952) and have produced higher counts in some experiments (Carlucci \& Pramer, 1957). Little use has been made of soil extracts for isolating marine bacteria, however, although Bayliss-Elliott (1930) and Turner \& Pugh (1961) used mud- and soil-extract media to isolate salt-marsh fungi. Burkholder (1959) added mud extract to media in an attempt to promote the growth of bacteria from salt-marsh samples and James (1959) used soil-extract agar for counting bacteria in inland saline soils.

The salinity of the medium may be even more important than the concentration of nutrients, although the literature on this topic is contradictory. Berkeley (1919), in a study of the bacteria present in coastal waters, noted that the sea water was of low density, clearly indicating freshwater dilution. Nevertheless, none of his isolates grew in freshwater media at room temperature. Similarly, Lipman (1926) showed that maximum counts of bacteria were obtained on media containing un-

* Present address: The Hartley Botanical Laboratories, The University, Liverpool 3. 
diluted sea water. Pearse, Humm \& Wharton (1942) and ZoBell (1959) reported essentially the same results for beach sand and marine mud. On the other hand, Lloyd (1930) found little or no difference between the counts obtained when water and mud from the Firth of Clyde were plated on saline or hardly saline media, whilst ZoBell (1941) obtained maximal counts of bacteria in mud and water from Mission Bay and San Diego Bay with media based on sea water diluted to 10-25\% of the original concentration. ZoBell (1946) attributed these differing results to different degrees of terrigenous contamination. Results such as these give little guidance in the selection of a medium for the bacteriological examination of estuarine salt-marsh muds. Thus before studying the distribution of bacteria in a salt marsh at Gibraltar Point, Lincolnshire, it was decided to investigate the relative merits of various saline and non-saline media and to compare soil-extract and mudextract media with the most widely used medium, namely ZoBell's no. 2216 sea-water agar.

\section{METHODS}

Sampling sites. The area being studied lay between a spit projecting in a southwesterly direction into the Wash and the River Steeping which flowed across the marsh some 500-600 yds. to the west. Samples of mud were collected from three sites in this area. These were: (1) the bank of the channel cut by the River Steeping through uncolonized mud flats, at a point which was covered by nearly all high tides; (2) the uncolonized mud at a point farther up the shore, covered by all but certain of the neap tides; (3) the salicornietum, which was covered only by the high spring tides. Samples of mud were also collected from the bank of the River Steeping at a point about 10 miles inland and well above the tidal region of the river.

Collection of samples. Samples of mud were obtained with a borer of diameter $5 \mathrm{~cm}$. These samples were placed in polythene beakers and taken to the laboratory, keeping their temperature at about $2^{\circ}$. Subsamples of mud were removed from these cores with a sterile borer and small quantities from a depth of $1 \mathrm{~cm}$. were placed in flasks containing $500 \mathrm{ml}$. sterile sea water (or river water for the non-saline mud) within $24 \mathrm{hr}$. of collection.

Methods of counting. The mud (about $0.5 \mathrm{~g}$.) which had been transferred to the dilution flask was dispersed with the aid of a sterile glass rod. Serial tenfold dilutions were prepared and three replicate plates of each medium were made from each dilution. In certain cases the most probable number method of counting was used, in which case sets of four tubes containing $5 \mathrm{ml}$. of each medium were inoculated with each dilution of mud suspension. After incubation for 14 days at $18^{\circ}$, the colonies that had developed were counted; or by using the McCrady probability tables (McCrady, 1918) estimates of the original numbers of bacteria in the mud were made. The contents of the dilution flasks were evaporated to dryness to find the dry weight of the mud used.

Media. Freshly collected meadow soil (Keuper marl with a cover of Dactylis glomerata) and mud from the salicornietum were used to prepare soil-extracts and mud-extracts by the method of James (1958). These extracts were made with sea water or river water; they were incorporated in various media used to count the bacteria in mud from the different sites.

Three liquid media, based on the formulae of Lochhead \& Chase (1943) and 
Taylor (1951) were used for the most probable number counts. These were as follows. Basal medium (medium $B$ ): glucose, $1.0 \mathrm{~g}$.; potassium nitrate, $0.5 \mathrm{~g}$.; ferric phosphate, $0.1 \mathrm{~g}$., dissolved in $1 \mathrm{l}$. artificial sea water $\left(\mathrm{NaCl}, 24.0 \mathrm{~g}\right.$.; $\mathrm{Na}_{2} \mathrm{SO}_{4}, 4.0 \mathrm{~g}$.; $\mathrm{MgCl}_{2} .6 \mathrm{H}_{2} \mathrm{O}, 11 \cdot 0$ g.; $\mathrm{CaCl}_{2} \cdot 6 \mathrm{H}_{2} 0,2 \cdot 0$ g.; $\mathrm{KCl}, 0 \cdot 7$ g.; $\mathrm{NaHCO}_{3}, 0 \cdot 2$ g.; $\mathrm{KBr}, 0 \cdot 1$ g.; $\mathrm{SrCl}_{2} .6 \mathrm{H}_{2} \mathrm{O}, 0.04$ g.; $\mathrm{H}_{3} \mathrm{BO}_{3}, 0.03$ g.; $\mathrm{Na}_{2} \mathrm{SiO}_{3} .9 \mathrm{H}_{2} \mathrm{O}, 0.005$ g.; NaF, 0.003 g.; demineralized water, 1 l. Medium $C G$ consisted of 1 l. basal medium $\mathrm{B}+$ vitamin-free casein hydrolysate (Difco), $4.0 \mathrm{~g}$.; inositol, $0.05 \mathrm{~g}$.; thiamin, $100 \mu \mathrm{g}$.; biotin, $0 \cdot 1 \mu \mathrm{g}$.; pyridoxin, 200.0 $\mu \mathrm{g}$; ; pantothenic acid, 100.0 $\mu \mathrm{g}$. ; nicotinic acid, 100.0 $\mu \mathrm{g}$. Medium $S Y$ consisted of $750 \mathrm{ml}$. basal medium $B+250 \mathrm{ml}$. meadow-soil extract made with artificial sea water $+0 \cdot 1 \mathrm{~g}$. yeast extract (Difco).

Six solid media, four of which were soil-extract or mud-extract media were used for a series of dilution plate counts. Sea-water and river-water extracts of meadow soil (media SS and SR) and of salt marsh mud (media MS and MR) were supplemented with $0.1 \mathrm{~g}$. ferric phosphate and $15.0 \mathrm{~g}$. agar (Oxoid Kobe no. 1). These were compared with ZoBell's medium no. 2216 (peptone, 5•0 g.; ferric phosphate, 0.1 g.; agar, 15.0 g.; sea water, 1 l.) and a variant of this medium made with river water (media ZS and ZR, respectively).

The effect of salinity of the medium was examined by means of further dilution counts on media ZS and ZR and on media of the same formula but made with artificial sea water or with solutions of sodium chloride in glass-distilled water at concentrations of $3.5 \%, \mathbf{1 0 . 0} \%$ and $20.0 \%(\mathrm{w} / \mathrm{v})$ (media $\mathrm{ZAS}$ and $\mathrm{ZNaCl}$ ). All these media were adjusted to $\mathrm{pH} \mathbf{7 \cdot 8}$ with sodium hydroxide immediately before use. The agar media were dispensed directly into Petri dishes by means of a sterile agarmedium dispenser (Gray, 1961).

Chloride determination. The chloride contents of the various mud samples were determined by titration of the soil solution with silver nitrate, with potassium chromate as an indicator (Piper, 1947).

\section{RESULTS}

The use of soil-extract and mud-extract media

The numbers of bacteria from three salt-marsh muds which developed in media B, CG and SY were determined by using the most probable number method. The results of five such experiments are given in Table 1. The numbers of bacteria which developed in media B and SY are expressed as a percentage of the number which developed in medium CG. The percentage of bacteria which grew in medium $B$ was low. There was little difference between the three sampling sites, the numbers of bacteria varying haphazardly between $0 \cdot 1$ and $3.2 \%$ of the numbers that grew in medium CG. Medium SY gave much larger counts, but except for the salicornietum bacteria, gave smaller counts than did medium CG. It was therefore considered that soil-extract media were probably of little advantage for counting salt marsh bacteria, at least as compared with nitrogenous media of known composition.

It is a commonly held view that the origin of soil for preparation of soil extract is of little consequence (Smith \& Worden, 1925; James, 1958). Nevertheless, in the present work it was thought that an extract of salt marsh mud might prove superior to an extract of meadow soil. To investigate this, dilution plates were poured with six media (ZS, ZR, SS, SR, MS, MR) to count the numbers of bacteria in the 
salicornietum mud. To test whether the non-saline mud would support growth, bacteria in mud from the freshwater site on the bank of the River Steeping were also counted. The results are given in Table 2. The numbers of bacteria capable of developing on the various media are all expressed as a percentage of those which developed on medium MS. The greatest number of colonies from the salicornietum mud developed on medium ZS and was three to four times as great as on medium MS. There were still fewer colonies on medium SS and very few on the non-saline media (ZR, MR, SR). In contrast, the higheșt counts of bacteria from the nonsaline mud samples were on the non-saline media; but again the peptone medium gave higher counts than the soil-extract and mud-extract media. Apparently mudextract media were less selective than soil-extract media.

Table 1. The relative numbers of bacteria developing in medium $B$ and medium $S Y$ when compared with medium $C G$

\begin{tabular}{|c|c|c|c|c|c|c|}
\hline \multirow{2}{*}{$\begin{array}{l}\text { Medium } \\
\text { B }\end{array}$} & \multirow{2}{*}{$\begin{array}{l}\text { Site } \\
\text { River Steeping (saline) } \\
\text { uncolonized mud } \\
\text { salicornietum }\end{array}$} & \multicolumn{5}{|c|}{$\begin{array}{l}\text { Numbers of bacteria in media } \mathrm{B} \text { and } \mathrm{SY} \\
\text { as percentage of those in medium CG } \\
\text { (five replicate experiments) }\end{array}$} \\
\hline & & $\begin{array}{l}0 \cdot 1 \\
0 \cdot 4 \\
0 \cdot 4\end{array}$ & $\begin{array}{l}1 \cdot 5 \\
1 \cdot 0 \\
0.2\end{array}$ & $\begin{array}{l}3 \cdot 2 \\
1 \cdot 4 \\
1 \cdot 0\end{array}$ & $\begin{array}{l}1 \cdot 8 \\
0 \cdot 3 \\
0 \cdot 4\end{array}$ & $\begin{array}{l}1 \cdot 4 \\
0 \cdot 2 \\
1 \cdot 4\end{array}$ \\
\hline SY & $\begin{array}{l}\text { River Steeping (saline) } \\
\text { uncolonized mud } \\
\text { salicornietum }\end{array}$ & $\begin{array}{r}70 \cdot 0 \\
43 \cdot 0 \\
100 \cdot 0\end{array}$ & $\begin{array}{r}43 \cdot 0 \\
25 \cdot 0 \\
100 \cdot 0\end{array}$ & $\begin{array}{r}32 \cdot 0 \\
46 \cdot 0 \\
140 \cdot 0\end{array}$ & $\begin{array}{r}55 \cdot 0 \\
100 \cdot 0 \\
17 \cdot 0\end{array}$ & $\begin{array}{r}80 \cdot 0 \\
45 \cdot 0 \\
1000 \cdot 0\end{array}$ \\
\hline CG & All three sites & $100 \cdot 0$ & $100 \cdot 0$ & $100 \cdot 0$ & $100 \cdot 0$ & $100 \cdot 0$ \\
\hline
\end{tabular}

Table 2. The numbers of bacteria/g. of oven-dry mud as determined on several media, expressed as percentage of the number on medium $M S$

\begin{tabular}{|c|c|c|c|c|c|}
\hline \multirow{3}{*}{ Medium } & \multicolumn{3}{|c|}{ Salicornietum mud } & \multicolumn{2}{|c|}{ Non-saline mud } \\
\hline & Sample 1 & Sample 2 & Sample $\mathbf{3}$ & Sample 2 & Sample $\mathbf{3}$ \\
\hline & \multicolumn{5}{|c|}{$\begin{array}{l}\text { Percentage of bacteria developing on various media } \\
\text { compared with medium MS }\end{array}$} \\
\hline $\mathbf{Z R}$ & - & 50 & 69 & 360 & 1950 \\
\hline ZS & 390 & 330 & B30 & 115 & 160 \\
\hline SR & 45 & 4 & 22 & 230 & 507 \\
\hline SS & 92 & 61 & 28 & 39 & 55 \\
\hline MR & 36 & $\mathbf{3 6}$ & 106 & 290 & 1,000 \\
\hline MS & 100 & 100 & 100 & 100 & 100 \\
\hline
\end{tabular}

The salinity of the medium

The use of saline and non-saline counting media was studied in greater detail. Table 3 summarizes the results of a series of dilution plate counts on media ZS and ZR. Mud from four sites was used: the salicornietum; uncolonized mud; uncolonized mud near the River Steeping; the freshwater mud referred to previously. The numbers of colonies developing on the non-saline medium are expressed as a percentage of those developing on the saline medium. The saline media again gave much higher counts for mud from the saline sites, whilst the non-saline medium gave higher counts for mud from the freshwater site. In the salicornietum, where 
high chloride concentrations were found (see Table 3 ) because of longer periods of tidal exposure, the percentage of bacteria which developed on the river water medium was particularly low, except in August, 1959.

Some attempts were made to subculture the salt-marsh bacteria which grew on the river-water medium on further river-water medium; growth was poor, however, and very poor when the isolates were reconstituted from freeze-dried cultures.

Table 3. The number of colonies on medium $Z R$ expressed as percentage of the colonies on medium $Z S$ in four sampling sites

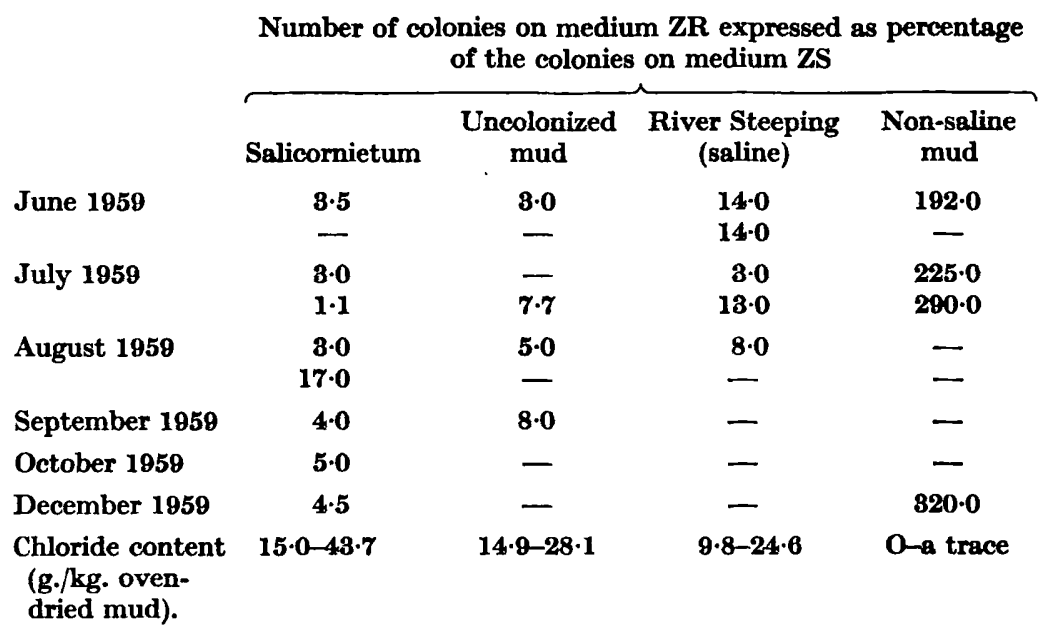

Table 4. The number of bacteria from the salicornietum developing on media of different salinities expressed as percentage of those developing on medium $\mathrm{ZS}$

\begin{tabular}{|c|c|c|c|}
\hline \multirow[b]{2}{*}{ Medium } & \multicolumn{3}{|c|}{$\begin{array}{l}\text { Number of bacteria developing on } \\
\text { different media as percentage of } \\
\text { those on medium ZS }\end{array}$} \\
\hline & Expt. 1 & Expt. 2 & Expt. 8 \\
\hline $\mathbf{Z S}$ & 100 & 100 & 100 \\
\hline ZAS & 105 & 94 & 90 \\
\hline $\mathbf{Z R}$ & 18 & 9 & 4 \\
\hline $\mathrm{ZNaCl}(8.5 \%)$ & 107 & 80 & 85 \\
\hline $\mathrm{ZNaCl}(10.0 \%)$ & $\mathbf{3 3}$ & 48 & 45 \\
\hline $\mathrm{ZNaCl}(\mathbf{2 0} \cdot 0 \%)$ & 18 & 16 & 80 \\
\hline
\end{tabular}

A second series of counts was made to compare medium $\mathrm{ZR}$ with a series of saline media, namely $\mathrm{ZS}, \mathrm{ZAS}$ and the three variants of $\mathrm{ZNaCl}$. The numbers of colonies which developed on the different media are recorded in Table 4, expressed as a percentage of the number which developed on medium ZS. Again, media of salinity about that of sea water gave the highest counts. There were comparatively small numerical differences between the counts on media $\mathrm{ZS}, \mathrm{ZAS}$ and $\mathrm{ZNaCl}(3.5 \%)$. However, the non-saline medium and the two media with high salt concentrations gave marked decreases in the counts obtained.

The appearance of the colonies on the different media also varied. Media $\mathrm{ZS}$ and 
ZAS supported a mixture of pigmented (yellow, red, orange) and non-pigmented forms, whilst on medium ZR most of the colonies were pigmented. Media made with sodium chloride supported very few pigmented colonies at all.

\section{DISCUSSION}

Previous workers have used soil extracts and mud extracts to isolate microorganisms from saline areas, with varying degrees of success. As far as fungi are concerned, Bayliss-Elliott (1930) found that other media were superior for isolation purposes. Similarly, Burkholder (1959) noted that the growth of marine bacteria was greatly stimulated by nitrogenous substances and Thalassia extracts, stimulated to some extent by dextrose, but not stimulated by the additions of mud-extract, or phosphate and ammonium nitrate. The results in the present work appear to support these results, and to show that soil-extract and mud-extract agars are not suitable for the enumeration of salt marsh bacteria. The only other report of the use of soil extracts to count bacteria from saline sites is that of James (1959) who investigated an inland saline area; he found that soil-extract media were superior to nitrogenous media. The reasons for this difference are obscure. For isolating organisms from salt marshes, as opposed to counting, mud extract may still prove useful as it may support a wider range of bacterial types than the peptone media used. Clearly the response of bacteria from saline sites to soil extracts and mud extracts needs further investigation.

The evidence also suggests that, contrary to the usual view (James, 1959) the origin of the soil used in preparing soil extract is of some importance, since salinemud extracts gave substantially larger counts than meadow-soil extracts. Starr (1956) showed that vitamin $B_{12}$ was produced more rapidly than it was destroyed in salt marshes, so that it is possible that mud extracts may contain a greater quantity or variety of growth factors than soil extracts.

The most satisfactory peptone media used in the present work were those based on sea water or artificial sea water; these gave slightly higher counts than a medium based on $3.5 \%$ sodium chloride. This is in agreement with the findings of Tyler, Bielling \& Pratt (1960) who showed that for marine bacteria, cations other than sodium were important for growth. River-water media, which apparently contained sufficient nutrients and growth factors to permit maximum counts of river-mud bacteria to be obtained, were unsuitable for salt-marsh bacteria, even for those isolated from close to the River Steeping. This reaction of salt-marsh bacteria has been confirmed by experiments on the effect of salinity on the growth of individual isolates (Gray, 1962). This evidence, together with the inability of the salt-marsh bacteria isolated on river-water media to grow well on subcultivation, indicates the possible marine origin of these bacteria. Macleod \& Onofrey (1956) reported that sea-water bacteria subcultured onto media of low salinity showed poor growth and often failed to survive more than one subculture. The possibility that terrestrial bacteria may become adapted to higher salinities cannot be ruled out however.

The origin of the mud in the marsh is of importance. Thus the present findings may not apply to all salt marshes. It was noted by Barnes \& King (1961) that at Gibraltar Point muddy sand was predominant, partly blown, but mainly washed over the spit or through a depression in it. In fact the main areas of accretion in the 
marsh that they examined were opposite this depression in the spit which separates the marsh from the North Sea. Hardy (1959) pointed out that there was an inflow of water from the North Sea into the Wash basin. Presumably, the predominant bacteria in the marsh will be derived from this mud and water. If large numbers of terrestrial bacteria are also swept into the area they must either be killed and replaced by marine forms or they must rapidly adapt themselves to saline conditions. It is possible that in other estuaries where it is known that the mud is largely of terrestrial origin, sea water media may prove to be less satisfactory for counting. Preliminary samples from the Humber estuary suggest that these muds contain rather more bacteria that would grow on non-saline media.

On the basis of the work described in this paper, an investigation into the distribution of bacteria in the Gibraltar Point salt marsh has been made. For this work, peptone media, namely ZoBell's medium no. 2216 and variants of it, were mostly used. The work is to be published later.

The work described formed part of a thesis submitted to the University of Nottingham for the degree of Ph.D. and was supported by a grant from the Department of Scientific and Industrial Research. The author wishes to thank Professor C. G. C. Chesters and Mrs M. Turner for their guidance and encouragement, Dr G. J. F. Pugh for many helpful suggestions and the Lincolnshire Naturalists Trust for permission to work in the Gibraltar Point reserve.

\section{REFERENCES}

Barnes, F. A. \& King, C. A. M. (1961). Salt marsh development at Gibraltar Point, Lincolnshire. East Midl. Geographer, 15, 20.

Bayliss-Eldiott, J. S. (1930). The soil fungi of the Dovey salt marshes. Ann. appl. Biol. $17,284$.

Berkeley, C. (1919). A study of marine bacteria. Straits of Georgia, B.C. Trans. Roy. Soc. Canad. (Ser. 3) 13, 15.

Burkholder, F. R. (1959). Some microbiological aspects of marine productivity in shallow waters. Proc. Salt-marsh Conf. Sapelo Island, 1958, p. 70.

Carlucci, A. F. \& Pramer, D. (1957). Factors influencing the plate method for determining the abundance of bacteria in sea water. Proc. Soc. exp. Biol., N.Y. 96, 392.

Fischer, B. (1894). Die Bakterien des Meeres bei den Untersuchungen der Plankton-Expedition unter gleichzeitiger Berücksichtigung einiger älterer und neuerer Untersuchungen. Ergebn. Plankton-Expedition der Humboldt-Stiftung, 4, 1.

GrAY, T. R. G. (1961). A sterile agar-medium dispenser. J. appl. Bact. $24,1$.

Gray, T. R. G. (1962). Effect of salinity on the growth of certain salt-marsh bacteria. Nature, Lond. 194, 560.

Hardy, A. C. (1959). The Open Sea. II. Fish and Fisheries. London: Collins.

Hudleston, M. (1955). Marine bacteria of Cardigan Bay. II. Bacteria in rock pools. J. appl. Bact. 18, 29.

James, N. (1958). Soil extract in soil microbiology. Canad. J. Microbiol. 4, 363.

JAMEs, N. (1959). Plate counts of bacteria and fungi in a saline soil. Canad.J. Microbiol. 5, 431.

LipMan, C. B. (1926). The concentration of sea water as affecting its bacterial population. J. Bact. 12, 311.

Lloyd, B. (1930). Bacteria of the Clyde sea area. A quantitative investigation. J. mar. biol. Ass. 16, 879.

Lochread, A. G. \& Chase, F. E. (1943). Qualitative studies of soil micro-organisms. V. Nutritional requirements of the predominant bacterial flora. Soil Sci. 55, 185. 
Macueod, R. A. \& Onofrey, E. (1956). Nutrition and metabolism of marine bacteria. II. Observations on the relation of sea water to the growth of marine bacteria. J. Bact. 71, 661.

McCrady, M. H. (1918). Tables for the rapid interpretation of fermentation tube results. Canad. Publ. Hlth J. 9, 201.

Oppenheimer, C. H. \& ZoBen, C. E. (1952). The growth and viability of sixty three species of marine bacteria as influenced by hydrostatic pressure. J. mar. Res. 11, 10.

Pearse, A. S., Humm, A. J. \& Wharton, C. W. (1942). Ecology of sand beaches at Beaufort, North Carolina. Ecol. Monogr. 12, 135.

Prper, C. S. (1947). Soil and Plant Analysis. Adelaide: University Press.

Smrth, N. R. \& Worden, S. (1925). Plate counts of soil micro-organisms. J. agric. Res. 31, 501.

Starr, T. J. (1956). Relative levels of vitamin $B_{12}$ in detritus from oceanic and estuarine environments. Ecology, 37, 658.

TAYLOR, C. B. (1951). Nutritional requirements of the predominant bacterial flora of soil. Proc. Soc. appl. Bact. 14, 101.

Turner, M. \& Pugr, G. J. F. (1961). Species of Mortierella from a salt-marsh. Trans. Brit. mycol. Soc. 44, 243.

Tyler, M. E., Bielling, M. C. \& Pratt, D. B. (1960). Mineral requirements and other characters of selected marine bacteria. J. gen. Microbiol. 23, 153.

Velankar, N. K. (1955). Bacteria in the inshore environment at Mandapam. Indian J. Fish. 2, 96.

Waksman, S. A. (1922). Microbiological analysis of soil as an index of soil fertility. II. Methods of study of the numbers of micro-organisms in soil. Soil Sci. 14, 283.

Wood, E. J. F. (1953). Heterotrophic bacteria in marine environments of Eastern Australia. Aust. J. fresh. mar. Res. 4, 160.

ZoBell, C. E. (1941). Studies on marine bacteria. I. The cultural requirements of heterotrophic aerobes. J. mar. Res. 4, 42.

ZoBeLL, C. E. (1946). Marine Microbiology Waltham, Mass., U.S.A.: Chronica Botanica Co.

ZoBerL, C. E. (1959). Introduction to marine microbiology. N.Z. Oceanogr. Inst. Mem. 3, Contrib. marine Microbiol. 7. 